\title{
The Effects of Local Government Size, Income per Capita, Local Government Wealth and Audit Opinion on the Quality of Internet Financial Reporting Disclosure: Studies in Indonesia
}

Eny Mariani ${ }^{*}{ }^{*}$, Wiwik Utami ${ }^{2}$

Mercu Buana Univesity Jakarta

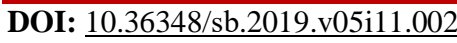

| Received: 21.10.2019 | Accepted: 28.10.2019 | Published: 11.11.2019

*Corresponding author: Eny Mariani

\section{Abstract}

This study was conducted with the aim to determine the effects of local government size, income per capita, local government wealth and audit opinion on the quality of internet financial reporting disclosures in local governments in accordance with Minister of Home Affairs Instruction No. 188.52/1797/SJ. The population in this study was all the official websites of the provincial governments in Indonesia, which covered 34 provinces. The samples in this study were all the official websites of the provincial governments in Indonesia with the observation years of 2015-2017, so the total amount of data in this study was 102 data ( 34 x 3 years). The samples in this study were selected using the survey data method on the official websites of the Provincial Governments in Indonesia. The results showed that the size of the local government had a significant effect on the quality of internet financial reporting disclosures in local governments, while income per capita, local wealth and audit opinion did not affect the quality of internet financial reporting disclosures in local governments.

Keywords: Quality of Financial Statements, Internet Financial Reporting, Local Government Size, Income Per capita, Local Government Wealth, and Audit Opinion.

Copyright @ 2019: This is an open-access article distributed under the terms of the Creative Commons Attribution license which permits unrestricted use, distribution, and reproduction in any medium for non-commercial use (NonCommercial, or CC-BY-NC) provided the original author and source are credited.

\section{INTRODUCTION}

Transparency is a key issue in the reformasi era, and the government must create accountability to the public by disclosing more financial information to increase public trust. Transparency in local financial management is emphasized by the issuance of Law of the Republic of Indonesia No. 14 of 2008 which states that the government is obliged to disseminate public information on any activities carried out in a manner that is easily accessible to the public and in language that is easily understood.

Following up the Law of the Republic of Indonesia No. 14 of 2008, the local governments, through the Ministry of Home Affairs, issued the Minister of Home Affairs Instruction Number $188.52 / 1797 / \mathrm{SJ} / 2012$ on the Improvement of Transparency in Local Budget Management instructing Governors, Regents and Mayors throughout Indonesia to prepare a content menu with the name "Transparency in Local Budget Management (TPAD)" which contains
12 budget management documents on the official websites of the local governments.

The coming into force of Republic of Indonesia Law No. 14 of 2008 and the Minister of Home Affairs Instruction Number 188.52/1797/SJ/2012 did not necessarily make local governments more transparent. This is in line with Martani and Fitriasari's [1] research which stated that the level of transparency of financial information and government performance had only reached $15 \%$ and the most frequently disclosed information related to financial information and local government performance was still in the form of news. As for key financial information and thorough performance information in the form of Regional Revenue and Expenditures Budget (APBD), financial statements and performance reports, the disclosure was still below 10\%. Furthermore, the Indonesian Forum for Budget Transparency (FITRA) 2019 states that the disclosure of budget data in the local governments' online portals is still low and there are still regions that are not yet transparent regarding their budget data; out 
Eny Mariani \& Wiwik Utami., Sch Bull, Nov 2019; 5(11): 611-619

of 34 provinces in Indonesia, only 23.5 percent provide the 2019 budget documents in their local portals.

An area with a large population and high income per capita generally has a better quality of life so that more and more community groups are aware of the function of financial statement information as a performance measure of the local government. This has led to more demands from the public that information on local government financial reports should be accessed more easily, cheaply, quickly and effectively.

A good government performance can be measured by how much Pendapatan Asli Daerah $(P A D)$ or Internally Generated Revenue (IGR) can add to the wealth of the Local Government and what opinion is given by the Financial Supervisory Agency (BPK) to the financial statements of the local government. This means the local government must reveal a signal to the public that the performance of the government is good so that public trust can continue to increase. According to Verawaty [2], Internet Financial Reporting (IFR) is the media that best meets the aspects of value of money or 3E (Efficiency, Effectiveness, and Economy) to provide and announce information about financial statements to all public stakeholders.

This study was conducted with the aim to answer these questions: 1) Does the size of the local government affect the quality of Internet Financial Reporting (IFR) disclosure?; 2) Does income per capita affect the quality of Internet Financial Reporting (IFR) disclosure?; 3) Does the local government's wealth affect the level of Internet Financial Reporting (IFR) disclosure? and 4) Does the audit opinion affect the level of =Internet Financial Reporting (IFR) disclosure?

\section{Literature study and hypothesis development Agency Theory}

This theory was introduced by Jensen Meckling [3] as a relationship between agents (management) and principals (shareholders). Agency relationship in government is the relationship between the people as the principals and the government as the agent. One of the causes of agency problems is the information asymmetry. Information asymmetry is an imbalance of information control between the agent and the principals (agency conflict) due to the agent having more information which results in problems for the principals to monitor and control the agent's actions. In government, financial reporting and information disclosure to the public are two forms of monitoring tools to reduce agency costs. Provision of information via the internet to the public can be used as a tool to reduce agency conflicts [4].

\section{Signalling Theory}

Signalling theory explains that the government as the party given the mandate from the people has an obligation to provide information to external parties. Generally there are two types of signals that will be disclosed by an agent, namely good signals (bad news) and bad signals (bad news). The government as the party given the mandate by the people would want to show a good signal to the community by providing quality financial reports, improving internal control systems, giving more complete disclosure, and providing more detailed explanation on the website [1]. A good signal (good news), if disclosed, will certainly improve the image of the government in the eyes of the public and will improve of services to public.

\section{Local Government Size}

Size is a scale or nominal that indicates how big or small an object is. Styles and Tennyson [5], Garcia [6] and Verawati [2] use the population as a proxy for the variable of local government size. According to the Indonesian Central Statistics Agency, residents are all people who have lived in the geographical area of the Republic of Indonesia for 6 months or more and or who have lived in the geographical area of the Republic of Indonesia for less than 6 months but aim to settle. (www.bps.go.id).

In general, residents are a group or a number of people who live in a country, while citizens are residents who live in a certain country based on the laws and regulations of that particular country. A resident does not have to be a citizen but a citizen is confirmed as the native of the region.

\section{Income Per Capita}

Income Per capita is the average income earned per person in a given area (city, region, country, etc.) in a specified year. Figures of income per capita benefit the government as: 1) State Welfare Indicator; 2) National Prosperity Growth Standard; 3) Guidelines for Government in Making Economic Policies and 4) Comparison of Inter-Country Prosperity Levels. In general, the income per capita can be calculated with Gross Domestic Product (GDP) or Gross National Product (GNP). There are two ways to calculate income per capita: 1) based on current prices and 2) based on constant prices.

\section{Local Government's Wealth}

Local government's wealth describes the level of prosperity of an area. Local wealth can be expressed by the Pendapatan Asli Daerah (PAD) or Internally Generated Revenue (IGR), which is one of the regional revenues sourced from the region itself that reflects the level of independence of the area [7].

According to Law No. 33 of 2004 Article 1, PAD is the right of the Local Government which is recognized as an addition to the net worth in the period of the year. Meanwhile, according to Article 6, the source of the PAD is the local legitimate own-source 
Eny Mariani \& Wiwik Utami., Sch Bull, Nov 2019; 5(11): 611-619

revenue and the revenue that comes from the central government grants. Regional income can be increased by intensifying, exploring new sources of revenue (extensification) and improving services to the community.

PAD is one indicator that determines the level of wealth of local government. PAD is a source of local revenue that is extracted from the area to be used to finance development and local businesses so that the region is able to reduce dependence on funds from the central government and ultimately becomes an independent region.

\section{Audit Opinion}

According to Abdul Halim [8], an audit opinion is a fairness conclusion on the information that has been audited. It is called fair in auditing if it is free from bias and dishonesty and is complete information. This is certainly still limited by the concept of materiality.

According to the Law of the Republic of Indonesia No. 15 of 2004 concerning the Audit of Management and Responsibility of State Finances, Opinion is a professional statement as an auditor's conclusions regarding the level of reasonableness of the information presented in the financial statements, which is based on the following criteria: 1) Conformity with government accounting standards; 2) Adequacy of disclosure; 3) Compliance with laws and regulations and 4) Effectiveness of internal control systems.

There are 4 (four) types of opinions that can be provided by auditors: 1) an unqualified opinion; 2) a qualified opinion; 3) an adverse opinion 4) a disclaimer of opinion.

\section{Internet Financial Reporting (IFR)}

Internet Financial Reporting is the way the government submits financial reports through the internet; it is expected to encourage the public to be able to participate effectively and efficiently in the running of government in Indonesia. Supporting this, through the Instruction of the Minister of Home Affairs No. 188.52/1797/SJ/2012 on Increasing Transparency in Regional Budget Management, the government instructed that no later than June 15, 2012, each local government must submit a content menu under the name "Transparency in Regional Budget Management" on their official website. The menu should contain 12 budget management documents: 1) Summary of RKA SKPD; 2) Summary of RKP PPKD; 3) Draft Regulation of APBD; 4) Draft Regional Regulation on APBD Amendment; 5) Regional Regulation of APBD; 6) Regional Regulation on APBD Amendment; 7) Summary of DPA SKPD; 8) Summary of DPA PPKD; 9) LRA SKPD; 10) LRA PPKD; 11) Audited LKPD and 12) BPK's Opinion on LKPD.
Some of the benefits that local governments can gain from disclosing accounting information via the internet include:

- The internet offers low costs to both users and information providers;

- Through the internet, information can be accessed by a wider user than the old communication media;

- The government can provide up-to-date information and offer timeliness in the dissemination and access to information so that information is more relevant;

- The government can increase financial statement disclosure by providing more detailed information compared to what is available in traditional annual reports;

- Internet allows users to interact with information providers in a way that is faster, easier and cheaper;

- The government can provide financial information in a variety of formats that are easily accessible and can be downloaded.

\section{The Effect of Local Government Size on the Quality of Local Government's Internet Financial Reporting (IFR) Disclosure}

Size is a scale or nominal that indicates how big or small an object is. A developed region has a larger population and has a better level of education than other regions, so that more financial information asymmetries must be reported to the public. This causes high monitoring and reporting costs, so as to reduce the costs the government must choose an easier, cheaper, faster and more effective financial information reporting media, which is the Internet Financial Reporting (IFR). According to Wiwik and Wahyuni (2017) in making decisions, relevant and timely financial and non-financial information is needed. Disclosure on the website is the best solution to be able to convey information in a timely manner.

According to Verawati [2] the bigger the city and the greater the population, then the higher the demand for accessibility of financial statement information is. Styles \& Tennyson, [5] states that cities with large populations are more likely to provide easier access to financial statement information on the internet.

\section{The Effect of Income Per Capita on the Quality of Local Government's Internet Financial Reporting (IFR) Disclosure}

Income per capita is often used as an indicator of the level of economic development of a country or region. Regions with high income per capita generally have a better quality of life, which is reflected in, among other things, life expectancy, health levels, and education levels, which means that more people are aware of the function of financial statement information as a measuring tool of the local government performance. 
Higher income per capita in an area means higher demand for accountability and wider internet use by the public.

\section{The Effect of Local Government's Wealth on the Quality of Local Government's Internet Financial Reporting (IFR) Disclosure}

Regional wealth reflects the performance of a local government. A local government with great wealth will try to show it to stakeholders as a signal of good public management. [1]. Regional wealth can be expressed by Pendapatan Asli Daerah (PAD) or Internally Generated Revenue (IGR). Pendapatan Asli Daerah (PAD) represents all money received through regional cash accounts which add to the equity of the fund. PAD consists of: 1) regional tax, 2) regional retributions, 3) results of the management of separated local assets, and 4) other legitimate sources of PADs. Small regional wealth indicates poor government performance, and a local government with poor performance will avoid voluntary disclosure and choose to limit the public's access to information. A local government that performs well will disclose more information and use better disclosure techniques in accordance with signaling theory. Publication of local gevernment's financial reports via the internet is a way for the local government to present their performance results easily and inexpensively. It can be concluded that the greater the wealth of a local government is, the more information is disclosed.

\section{The Effect of Audit Opinion on the Quality of Local Government's Internet Financial Reporting (IFR) Disclosure}

According to Law No. 15 of 2004 concerning the Audit of State Financial Management and Accountability, an audit opinion is a professional statement as the auditor's conclusions regarding the level of reasonableness of the information presented in the financial statements. The auditor's opinion is considered as a reflection of the quality of the financial statements. Wajar Tanpa Pengecualian (WTP) or Unqualified Opinion is given to entities with good financial statements and free from material misstatement. Whereas Tidak Memberikan Pendapat $(T M P)$ or a disclaimer of opinion is given when there are extraordinary scope limitations so that the auditor does not obtain sufficient evidence as a basis for giving an opinion. These audit opinions will later be used as a measurement of the performance of a local government, whether the quality of their financial accountability is good or not.

According to signaling theory, there are two kinds of signals expressed by companies: good signal (good news) and bad signal (bad news). A good signal if disclosed will make a good impression with investors and increase public trust. Styles and Tennyson [5] stated that local governments that receive awards from external organizations for good financial reporting practices tend to present their financial reports on the internet. The form of appreciation received by the local governments for their success in presenting a good financial report can be seen from the opinion given by the Financial Supervisory Agency (BPK). Higher opinions given by BPK are expected to encourage the local governments to fully disclose their financial statements.

\section{HYPOTHESIS}

Based on the above framework, the research hypothesis to be tested can be formulated as follows:

$\mathrm{H}_{1}=$ Local Government size has a positive effect on the quality of the Local Government's Internet Financial Reporting (IFR) disclosure

$\mathrm{H}_{2}=$ Income Per Capita has a positive effect on the quality of the Local Government's Internet Financial Reporting (IFR) disclosure

$\mathrm{H}_{3}$ = Local Government's Wealth has a positive effect on the quality of the Local Government's Internet Financial Reporting (IFR) disclosure

$\mathrm{H}_{4}=$ Audit Opinion has a positive effect on the quality of the Local Government's Internet Financial Reporting (IFR) disclosure

\section{RESEARCH METHODS}

This research is a causal study that aims to test the hypothesis about the effect of one or several variables (independent variables) on other variables (dependent variables).

The population used in this study is the provincial governments in Indonesia, where currently there are 34 provinces in the country. The object of this research is the completeness of local financial information disclosures through the official website of the provincial governments in Indonesia. The intended information is the local financial information that is required in the Minister of Home Affairs Instruction No.188.52/1797/SJ of 2012 concerning the Improvement of Regional Budget Management Transparency (TPAD). 
Table-1: Variable Operationalization

\begin{tabular}{|c|c|c|c|}
\hline Variable & Dimension & Indicator & $\begin{array}{c}\text { Scale of } \\
\text { Measurement }\end{array}$ \\
\hline \multicolumn{4}{|l|}{ Dependent } \\
\hline $\begin{array}{l}\text { Quality of local } \\
\text { government's } \\
\text { Internet Financial } \\
\text { Reporting } \quad \text { (IFR) } \\
\text { disclosure }\end{array}$ & $\begin{array}{l}\text { Measured using IFR disclosure } \\
\text { index indicators that refer to } \\
\text { Minister of Home Affairs } \\
\text { Instruction No. } 188.52 / 1797 / \mathrm{SJ} \\
2012 \\
\text { If in accordance with the criteria, } \\
\text { a corresponding score is given; if } \\
\text { not, the score is 0 }\end{array}$ & $\begin{array}{l}\text { INDEX }=\mathbf{n} / \mathbf{k} \\
\mathrm{n}=\text { number of IFR disclosure items } \\
\text { presented by local government } \\
\mathrm{k}=\text { number of IFR disclosure items that } \\
\text { must be presented by the local } \\
\text { government }\end{array}$ & Ratio scale \\
\hline \multicolumn{4}{|l|}{ Independent } \\
\hline $\begin{array}{l}\text { Local government } \\
\text { size }\end{array}$ & $\begin{array}{l}\text { Measured by population log of } \\
\text { local government } \mathrm{i} \text { in year } \mathrm{i}\end{array}$ & Log $=$ Total Population & Ratio scale \\
\hline Income Per Capita & $\begin{array}{l}\text { Measured by GRDP per capita } \\
\log \text { of local government } i \text { in year } \\
i\end{array}$ & $\begin{array}{l}\text { GRDP per capita is based on current } \\
\text { prices } \\
\text { Log }=\text { GRDP per capita }\end{array}$ & Ratio scale \\
\hline $\begin{array}{l}\text { Local government's } \\
\text { wealth }\end{array}$ & $\begin{array}{l}\text { Measured by the ratio of total } \\
\text { IGR to the total population of } \\
\text { area } i \text { in year i }\end{array}$ & Wealth $=\frac{\text { Total IGR }}{\text { Total Population }}$ & Ratio scale \\
\hline Audit Opinion & $\begin{array}{l}\text { measured by dummy variables, ie } \\
\text { local governments with } \\
\text { Unqualified Opinion are given a } \\
\text { score of } 1 \text {, while those with } \\
\text { opinions other than Unqualified } \\
\text { Opinion are given a score of } 0\end{array}$ & $\begin{array}{l}\text { Audit opinion given by BPK to local } \\
\text { government on LKPD in year i in BPK } \\
\text { RI's Summary of Semester Inspection } \\
\text { Results (IHPS) of year i }\end{array}$ & Nominal \\
\hline
\end{tabular}

\section{Source: Literature review results, July 2019}

\section{RESULTS AND ANALYSIS}

The population in this study was all the official websites of the provincial governments in Indonesia, which covered 34 provinces. The samples in this study were all the official websites of the provincial governments in Indonesia with the observation years of 2015-2017, so the total amount of data in this study was 102 data ( $34 \times 3$ years). The samples in this study were selected using the survey data method on the official websites of the Provincial Governments in Indonesia.

\section{Descriptive statistics}

Descriptive statistics aim to see the distribution of data used as a sample. Descriptive statistics describe the distribution of data consisting of minimum score, maximum score, average score, and standard deviation score for the data used in this study.

Table-2: Descriptive Statistics Results

\begin{tabular}{|l|c|r|r|r|r|}
\hline & N & \multicolumn{1}{|c|}{ Minimum } & \multicolumn{1}{c|}{ Maximum } & \multicolumn{1}{c|}{ Mean } & Std. Deviation \\
\hline Size & 102 & $641.940,00$ & $48.037 .600,00$ & $7.628 .009,11$ & $10.784 .475,90$ \\
\hline Income & 102 & $11.087 .910,00$ & $157.684 .470,00$ & $39.300 .203,43$ & $29.794 .918,40$ \\
\hline Wealth & 102 & $172.324,00$ & $3.999 .170,00$ & $514.795,06$ & $589.543,79$ \\
\hline Opini & 102 & 0 & 1 &, 91 &, 285 \\
\hline IFR & 102 & 0 & 100 & 30,72 & 34,549 \\
\hline Valid N (listwise) & 102 & \multicolumn{7}{|c|}{ Source: Results of data processing SPSS 23, 2019 } \\
\hline
\end{tabular}

a. Population Variable (Size)

From the results of data processing, it is known that the minimum score is 641,940 people (North Kalimantan Province in 2015), the maximum score is 48,037,600 people (West Java Province in 2017), the average score is $7,628,009$ people, and the standard deviation is $10,784,475.90$ people.

b. Income Per Capita Variable (Income)
From the results of data processing, it is known that the minimum score is Rp11,087,910 per year (NTT Province in 2015), the maximum score is Rp157,684,470 per year (DKI Jakarta Province in 2017), the average score of the Income variable is Rp39,300,203.43 and the standard deviation is Rp.29,794,918.40 per year.

c. Local Government Wealth Variable (Wealth) 
From the results of data processing, it is known that the minimum score is Rp172,324 (NTT Province in 2015), the maximum score is Rp3,999,170 (DKI Jakarta Province 2017), the average score is Rp514,795.06 and the standard deviation is Rp589,543.79

d. Audit Opinion Variable (Opinion)

This variable is a dummy variable so the minimum score is 0 and the maximum score is 1 . A minimum score of 0 is given to the LKPD with a NonUnqualified Opinion, which is 9 or $8.82 \%$; and a maximum score of 1 is given to the LKPD with Unqualified Opinion, which is 102 or $91.18 \%$. The average score of this variable is 0.91 of all audit opinions and the standard deviation of the opinion variable is 0.285 .

e. Variable of Internet Financial Repoting (IFR) Practice Index

22 or $21.57 \%$ have a minimum score of $0 ; 12$ or $11.76 \%$ have a maximum score of 100 ; the average score is 30.72; and the standard deviation of the IFR variable is 34,549 .

\section{Classical Assumption Test}

\section{Normality Test}

Based on the One Sample Kolmogorov Smirnov test, the Asymp value, Sig. (2-tailed) of 0.200 is greater than the significant level of $5 \%$ or 0.05 . This indicates that residuals are stated to be normally distributed or independent variables consisting of Total Population (Size), Income Per Capita (Income), Local Government Wealth, and Audit Opinion (Opinion) having normally distributed data

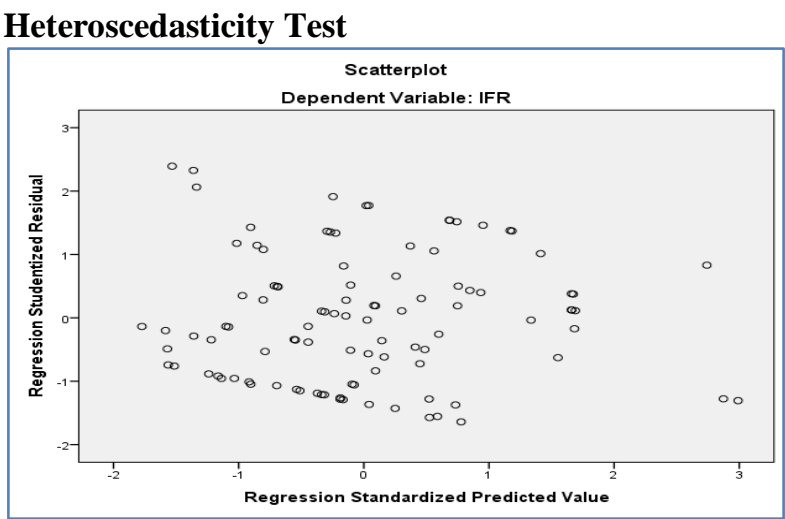

Fig-2: Heteroskedacity Test Results

From the scatterplots graph it can be seen that the points spread randomly and are spread both above and below the number 0 on the $\mathrm{Y}$ axis. This means there was no heteroscedasticity in the regression model, so the regression model was feasible to be used in this study.

\section{Autocorrelation Test}

The autocorrelation test in this study used the Durbin-Watson Test. A model is said to be free from autocorrelation if dU < $<4-\mathrm{dU}$, Ghozali [11]. Based on the Autocorrelation Test - Cochrane Orcutt, the Durbin Watson value was 1.990. This means du $<\mathrm{d}<4-\mathrm{du}$ $(1,760<1,990<2,240)$, so it can be concluded that there is no autocorrelation.

\section{Multicollinearity Test}

According to Lela [12], Multicollinearity can be detected by looking at the Tolerance Value and Variance Inflation Factor (VIF). Regression model is said ro be free of multicollinearity if the VIF value $<10$ and tolerance value $>0.1$, thus it can be concluded that there is no multicollinearity. The VIF and tolerance value are obtained from the analysis results.

Table-3: Multicollinearity Test Results

\begin{tabular}{|c|c|c|c|c|}
\hline \multicolumn{4}{|c|}{ Coefficients $^{\mathrm{a}}$} & \multirow{3}{*}{ Results } \\
\hline & \multirow{2}{*}{ Model } & \multicolumn{2}{|c|}{ Collinearity Statistics } & \\
\hline & & Tolerance & VIF & \\
\hline \multirow{5}{*}{1} & (Constant) & & & \\
\hline & Size & 0,932 & 1,073 & there is no multicollinearity \\
\hline & Income & 0,382 & 2,616 & there is no multicollinearity \\
\hline & Wealth & 0,357 & 2,802 & there is no multicollinearity \\
\hline & Opini & 0,888 & 1,126 & there is no multicollinearity \\
\hline \multicolumn{4}{|c|}{ a. Dependent Variable: IFR } & \\
\hline
\end{tabular}

Based on the multicollinearity test, the results of all independent variables have a tolerance value $>0.1$ and a VIF value $<10$, so there is no multicollinearity between the independent variables in the regression model. 
Eny Mariani \& Wiwik Utami., Sch Bull, Nov 2019; 5(11): 611-619

Hypothesis Test

Coefficient of Determination Test $\left(\mathbf{R}^{2}\right)$

A Coefficient of Determination Test $\left(\mathrm{R}^{2}\right.$ test) produces an adjusted $\mathrm{R}^{2}$ value of 0.094 in table 3 . This Partial Significance Test (t Test)

Table-4: Hasil Uji Signifikansi Parsial (Uji t)

\begin{tabular}{|l|l|r|r|r|r|}
\hline \multicolumn{2}{|c|}{ Model } & \multicolumn{1}{|c|}{ Coef } & \multicolumn{1}{c|}{ t } & \multicolumn{1}{c|}{ Sig. } & Hipotesis \\
\cline { 3 - 6 } \multicolumn{2}{|c|}{1} & B & & & \\
\cline { 2 - 6 } & (Constant) & $-277,974$ & $-2,473$ & 0,015 & \\
\cline { 2 - 6 } & Size & 21,751 & 2,887 & 0,005 & accepted \\
\cline { 2 - 6 } & Income & 4,385 & 0,203 & 0,84 & Rejected \\
\cline { 2 - 6 } & Wealth & 25,47 & 1,081 & 0,283 & Rejected \\
\cline { 2 - 6 } & Opini & 0,623 & 0,052 & 0,959 & Rejected \\
\hline a. & Dependent Variable: IFR & & \\
\hline
\end{tabular}

Source: Results of data processing SPSS 23, 2019

\section{Simultaneous Significant Test (Test F)}

Based on the regression analysis, it appears that all independent variables - the size of the local government, income per capita, local government wealth and audit opinion on the Internet Financial Repoting - simultaneously affect the dependent variables. This is evidenced by the significance of the F-test value of 0.009 , where the significance value is less than 0.05 or $5 \%$.

\section{The Size of Local Government has a Positive Effect on the Quality of Local Government's Internet Financial Repoting (IFR) Disclosure}

Based on the results of statistical significance test, the variable of local government size, which is proxied by the population, shows t-count of $2.887>\mathrm{t}$ table of 1.985 and significance value $(0.005)<\alpha(0.05)$ with a positive coefficient value of 21.751 . Thus, the size of the local government affects the quality of Local Government's Internet Financial Repoting (IFR) disclosure. The results of this study are in line with research conducted by Styles \& Tennyson [5], which was supported by research by Trisnawati and Achmad [13], that states that cities with larger populations are more likely to provide easier access to financial statement information on the Internet. However, this study is not in line with research conducted by Verawaty [2], which did not find a relationship between the size of local governments and the Internet Financial Repoting (IFR).

A developed region has a larger population and has a better level of education than other regions, so that more financial information asymmetries must be reported to the public. This causes high monitoring and reporting costs, so as to reduce the costs the government must choose an easier, cheaper, faster and more effective financial information reporting media. Internet Financial Repoting (IFR) is a method of financial information reporting that utilizes the internet, which is more efficient and effective than the traditional methods through manual distribution to stakeholders. means that the variation of the dependent variables that can be explained by the independent variables is $9.4 \%$, while the rest, $90.6 \%$, is explained by other variables that are not examined.

Income Per Capita has a Positive Effect on the Quality of Local Government's Internet Financial Repoting (IFR) Disclosure

The results of statistical tests conducted in this study indicate that income per capita has $t$-count of $0.203<\mathrm{t}$-table of 1.985 and a significance value of $(0.840)>\alpha(0.05)$ with a positive coefficient value of 4.385. Thus income per capita does not directly influence local governments to practice internet financial reporting on their websites. This is because income per capita does not reflect income distribution in an area. Other factors, such as education level and internet network access, are reasons for residents in the regions to want to access this information more easily, cheaply, quickly and effectively.

This study is not in line with Styles \& Tennyson [5] which found a relationship between Internet Financial Reporing and income per capita, but in line with Verawaty [2] research which found no relationship between Internet Financial Reporing and income per capita.

Local Government Wealth has a Positive Effect on the Quality of Local Government's Internet Financial Repoting (IFR) Disclosure

The results of statistical tests carried out in this study showed that the local government wealth has a tvalue of $1.081<\mathrm{t}$-table of 1.985 and a significance value of $(0.283)>\alpha(0.05)$ with a positive coefficient value of 25.470 . Thus the local government's wealth does not influence local governments to present internet financial reporting practices on their websites. This is because the local governments do not think that disclosure of financial information such as LKPD on the website is really needed as evidenced by the small number of local governments that disclose their LKPD on their official websites. This is made worse by the tendency of the public to only carry out obligations such as paying taxes and fees without wanting to know more about the performance of their local governments in managing the local assets. 
This research is in line with the Nosihana and Yaya [14] study. However, it is different from the research of Jimoh and Okoye [15], Rahman et al. [16], Trisnawati and Achmad [13] and Setyowati [17] which stated that there is a relation between local government wealth and financial reporting on the internet.

\section{Audit Opinion has a Positive Eeffect on the Quality of Local Government's Internet Financial Repoting (IFR) Disclosure}

The results of statistical tests conducted in this study showed that the Audit Opinion has a value of 0.052 <ttable of 1.985 and a significance value of $(0.959)>\alpha(0.05)$ with a positive coefficient value of 0.623. Therefore, local governments that obtain unqualified audit opinions from BPK RI do not all carry out internet financial reporting practices on their websites. This is because an unqualified audit opinion does not always indicate a good government performance or a government that is free from corruption [14] and a non-unqualified audit opinion does not always indicate poor government performance and accountability because government performance is not only measured by finance reports only. Local governments have not considered disclosure of financial information on the website as necessary. Moreover, inadequate technological infrastructure and human resource capabilities also play a role in this failure.

This research is in line with the Nosihana and Yaya [14] study, which stated that Audit Opinion has no effect on IFR, and [18] study, which stated that local governments that obtain unqualified opinions do not necessarily practice internet financial reporting in their websites well.

\section{CONCLUSIONS}

- The size of the local government which is proxied through the population has a positive and significant effect on the quality of local governments' IFR disclosure. This means that some developed regions have a larger population and have a better level of education than other regions, so the demand for financial information to measure the performance of local governments is higher.

- Income per capita has no effect on the quality of local governments' IFR disclosure. This is because income per capita does not show income equality in an area. Level of education and internet network access are also factors of whether the population in the area want such information to be accessed more easily, cheaply, quickly and effectively.

- Local government wealth does not affect the quality of local governments' IFR disclosure. This is due to the tendency of the people to only carry out obligations such as paying taxes and fees without wanting to know more about the performance of their local governments in managing the assets in the area.
- Audit opinion does not affect the quality of local governments' IFR disclosure. This is because the local governments still consider that disclosure of financial information on the website is not as important. Other reasons include inadequate technological infrastructure and human resource capabilities.

\section{SUGGESTIONS}

Based on the data analysis results, conclusions and limitations in this study, suggestions that can be submitted are as follows:

- Regulators are expected to provide sanctions for local governments that do not implement IFR and awards for local governments that have implemented IFR. This is because the Minister of Home Affairs Instruction number 188.52 / 1797 / SJ dated May 9, 2012 states that all local governments must fill the TPAD content with 12 items of financial information on the region's official website. However, it does not state sanctions as a deterrent effect on local governments that do not implement IFR so that local governments consider disclosure of financial information on the website to be of little importance. This is evidenced by the disclosure value which only reaches $42.76 \%$;

- The researcher only examined the availability of financial information at the level I local government website, so the next researcher is expected to broaden the base of the analysis by adding a level II local government as further research material;

- The next researcher is expected to be able to add other variables that may influence the quality of IFR disclosure, such as education level, demographics, dependency level, and level of population welfare.

\section{REFFERENCE}

1. Puspita, R., \& Martani, D. (2012). Analisis pengaruh kinerja dan karakteristik pemda terhadap tingkat pengungkapan dan kualitas informasi dalam website pemda. Universitas Indonesia.

2. Verawaty, V. (2015). Determinan aksesibilitas internet financial reporting melalui e-government pemerintah daerah di Indonesia.

3. Jensen, M. C., \& Meckling, W. H. (1976). Theory of the Firm: Managerial Behavior, Agency Costs and Ownership Structure. Journal of Financial Economics, 3(4): 303-360.

4. Rosita, L. R. A., \& Arifin, J. (2017). Determinan Kualitas Pengungkapan Laporan Keuangan dalam Website Pemerintah Daerah. Simposium Nasional Akuntansi XX Jember, 1-26, September 2017.

5. Styles, A. K., \& Tennyson, M. (2007). The Accessibility of Financial Reporting of U.S. Municipalities on The Internet. Journal of Public 
Budgeting, Accounting \& Financial Management, 19(1): 56-92.

6. García, A. C., \& García-garcía, J. (2010). Determinants of Online Reporting of Accounting Information by Spanish Local Government Authorities. Local Government Studies, 36(5): 679-695.

7. Setyaningrum, D., \& Syafitri, F. (2012). Analisis Pengaruh Karakteristik Pemerintah Daerah Terhadap Tingkat Pengungkapan Laporan Keuangan. Jurnal Akuntansi Dan Keuangan Indonesia, 9(2): 154-170.

8. Abdul Halim. (2013). Akuntansi Keuangan Daerah. Salemba Empat: Jakarta

9. Hanifah, F. F., Suryarini, T., \& Mukibad, H. (2017). Pengaruh Kompetisi Politik , IPM , dan Leverage Terhadap Ketersediaan dan Keteraksesan Informasi Keuangan Daerah. Simposium Nasional Akuntansi XX Jember, 1-23, September 2017.

10. Kpk.go.id.(2018). Indeks Persepsi Korupsi 2017, Skor Indonesia di Angka 37 Diakses pada Februari 2019 https://www.kpk.go.id/id/berita/beritakpk/229-indeks-persepsikorupsi-2017-skorindonesia-di-angka-37.

11. Ghozali, Imam. 2013. Aplikasi Analisis Multivariate dengan Program SPSS. Edisi Ketujuh. Semarang : Badan Penerbit Universitas Diponegoro:

12. Lela Nurlaela Wati. (2018). Metodologi Penelitian Terapan. Jakarta : Pustaka Amri

13. Trisnawati, M. D., \& Achmad, K,. 2014. Determinan Publikasi Laporan Keuangan
Pemda melalui Internet. Simposium Nasional Akuntansi XVII. Mataram. Lombok.

14. Nosihana, A., \& Yaya, R. (2016). Internet Financial Reporting dan Faktor-Faktor yang Mempengaruhinya pada Pemerintah Kota dan Kabupaten di Indonesia. Jurnal Dinamika Akuntansi Dan Bisnis, 3(2): 89-104.

15. Jimoh, J., \& Okoye, A.F. (2016). Voluntary Internet Financial Reporting In The Nigerian Public Sector. Igbinedion University Journal Of Accounting, 2 : 40-61

16. Rahman, A., Sutaryo., \& Budiatmanto, A. (2013). Determinan Internet Financial Local Government Reporting di Indonesia. Simposium Nasional Akuntansi XVI Manado, 25-28, September 2013.

17. Khasanah, I. N., Yuhertiana, I., \& Setyo, G. (2017). Determinan Aksesibilitas Internet Financial Reporting (IFR) Pemerintah Ibu Kota Provinsi di Indonesia. Simposium Nasional Akuntansi XX Jember, 1-20, September 2017

18. Setiyawati, H. (2013). The effect of Internal Accountants' Competence, Managers' Commitment to Organizations and the Implementation of the Internal Control System on the Quality of Financial Reporting. International Journal of Business and Management Invention, 2(11), 19-27.

19. Wiwik Utami, \& PD Wahyuni. (2019). The quality of corporate internet reporting in Indonesia stock exchange. Religación. Revista de Ciencias Sociales y Humanidades 4 (17), 674-680 